\title{
Potential of productivity of perennial grasses in one-way and mixed sowings on sewed peat soils of Western Polissia
}

\author{
Tarariko Yu. \\ Corresponding Member of NAAS, Doctor of Agricultural Sciences \\ Stetsiuk M. \\ Zosymchuk M. \\ Candidate of Agricultural Sciences
}

The purpose. To determine potential of productivity of perennial cereal grasses in one-way and mixed grass stands, optimum species composition of grass mixtures, regime of fertilizing and mowing grass stand at growing grasses on sewed peat soils of Western Polissia. Methods. Field, laboratory, dispersion analysis. Results. Outcomes of long-term probes on influence of fertilizing and regime of mowing upon productivity of main perennial grasses and their grass mixtures on sewed soils of Western Polissia are brought. Conclusions. It is determined that the most fruitful among perennial cereal grasses on sewed peat soils are the following species: Phalaris arundinacea, Brōmus inērmis, Phléum, Alopecúrus and Beckmánnia. In oneway grass stands these crops at long use ensure average productivity of hay more than 10-12 t/hectare. Among grass mixtures of long-term use for hay the most productive one is the mixture of Phléum, Festuca pratensis or Dáctylis glomeráta at obligatory presence of Brōmus inērmis.

Key words: sewed peat soils, meadow culture, perennial grasses, regime of mowing of grass stand.

Raising of problem. The basis of creating a strong and full-fledged livestock forage in the zone of Western Polissya are perennial herbs having a high productivity and feed value, takes the first place among other groups of fodder crops and play an important role in maintaining the fertility of the soil [1-5]. The problem of grassland farming on drained peat soils subject of many studies [6-8], but it remains still relevant. In particular the importance of the correct selection of appropriate species of grasses and the formation of grass mixture, which would provide high performance and long-term use of grass for good quality food.

Agricultural use of drained peat soils is of particular relevance because the processes of Genesis, occurring in peat soils after drainage, requires a specific other soil systems for agricultural use. The process of anthropogenic evolution of peat soils turning them into mineral. This process can be slow growing perennial herbs because they reduce the intensity of mineralization of peat organic matter [3, 9, 10, 11].

When you create herbage hayfield use on drained peat lands traditional kinds of perennial grasses are phleum pretense, dactilys glomerata, bromus inermis, trifolium pretense, trifolium hybridum [1, 6, 12]. However, scientific studies $[1,4,5]$ it is proved that not all types of meadow grasses, particularly legumes, and their grass mixture on reclaimed peat soils can provide higher and more stable yields, especially in long term use of grass.

In this context there is the need to analyze the available experimental material on the management of grassland farming on drained peat soils of Western Polissya. To assess the yield of meadow grasses in single-species and mixed crops, their productive longevity, the effect of fertilizer and mowing on the productivity of grasses was analyzed the results of many years of experimental studies Sarny experimental station of Institute of water problems and land reclamation of NAAS.

Aim of researches. To establish the potential of yield of perennial grasses and their productive longevity of single and mixed grass fields, optimal species composition of grass mixers, fertilizer regime and mowing of grass when growing grasses on dewatered peat soils of Western Polissya.

Methodology of realization of researches. For many decades, the Sarnen Experimental Station of the Institute of Water Problems and Melioration has been carrying out research on the use of depleted peat soils. Much of the research is devoted to the study of the productivity of herbs and their grass mixtures for different fertilizer and mowing regimes. In order to establish the most optimal elements of mowing technology on drained peat soils, for the comprehensive analysis, the results of 3 field experiments were selected, in 
which the traditional and short-lived species of perennial meadow grasses and their mixtures were studied, and various fertilizer and mowing regimes were used herbage.

In the 1 field experiment during 1982-2007, the productivity of single-species crops of perennial herbs was studied. Single-grassy herbs were laid with broad-sowing crops (for ridge root crops, intercropping 45-50 $\mathrm{cm}$, for others $30-40 \mathrm{~cm}$ ), the optimum seeding standards were used [6]. To determine the potential of each species, the same agrotechnics were used for all herbs: spring fertilization with phosphoric-potash fertilizers $\left(\mathrm{P}_{60} \mathrm{~K}_{120}\right)$, if necessary, nitrogenous $\left(\mathrm{N}_{30}\right)$, 3-way multi-row soil cultivation, species propagation. Area of experimental sites $-36 \mathrm{~m}^{2}$, repetition of 4 year, table 1 .

In the 2 field experiment that was conducted during 1996-2002, 8 grass mixtures of perennial grasses were studied for the following fertilization options: $\mathrm{P}_{60} \mathrm{~K}_{120}$ and $\mathrm{N}_{120} \mathrm{P}_{60} \mathrm{~K}_{120}$. In the experiments, a 2-degree mode of grass mowing was used. The size of the experimental sites is $50 \mathrm{~m}^{2}$, the repetition is 4 times. The composition of grass mixes and the weight of components are presented in table 2.

In the 3 field experiment conducted during 2008-2010, the productivity of single-species crops of perennial herbs and their grass mixtures was studied. The composition of grass mixers and the weight component of the components $(\mathrm{kg})$ was as follows: grass mix 1 - bromus inermis $(4,3)$, phleum pretense $(4,3)$, lolium perenne $(4,3)$, beckmannia eruciformis $(4,3)$, festuca ovina $(4,3)$, lotus corniculatus $(4,3)$, lotus uliginosus (4,3); grass mix 2 - bromus inermis (10), phleum pretense (10); lolium perenne (10), grass mix 3 bromus inermis $(7,5)$, phleum pretense $(7,5)$, lolium perenne $(7,5)$, lotus corniculatus $(7,5)$; grass mix $4-$ bromus inermis $(7,5)$, phleum pretense $(7,5)$, lolium perenne $(7,5)$, lotus uliginosus $(7,5)$. The investigated species of perennial grasses and their grass mixtures were studied in 2 and 3 slope mowing conditions against the background of the following fertilization options: no fertilizers; $\mathrm{P}_{60} \mathrm{~K}_{120} ; \mathrm{N}_{60} \mathrm{P}_{60} \mathrm{~K}_{120}$. The size of the experimental sites is $36 \mathrm{~m}^{2}$, the repetition is 3 times.

The research was carried out on a peeled peat bogs "Chemerne", which, according to morphological characteristics, botanical composition, water-physical and agrochemical properties, is typical for the Western Polissya, with a deep, medium-flowing, non-flooded hypnotic-sedge mire of low-lying type. The soil of experimental sites has a slightly acidic reaction $\mathrm{pH} 4,8-5,0$, well-equipped with easily hydrolyzed nitrogen, low phosphorus content and very low potassium.

Results of researches and their analysis. For studying the productivity potential of perennial grasses in depleted peatlands during 1982-2007, 13 species of plant breeding herbs were examined (table 1): widely cultivated in the reclaimed peat lands of the region - phleum pretense, festuca pratensis, bromus inermis, dactilys glomerata, festuca arundinacea schreb; typical for natural lands on peat soils - alopecurus pratensis, phalaris arundinacea, beckmannia eruciformis, poa palustris, festuca rubra, agrostis gigantean roth; rarely cultivated and non-typical for the given conditions - lolium perenne and festuca ovina, which in mixed herbage on organogenic soils can not withstand the type of competition and conditions of hibernation.

\section{The potential productivity of meadow grasses in single-species mixtures of prolonged use on drained peat soils}

\begin{tabular}{|l|l|l|l|}
\hline \multirow{2}{*}{$\begin{array}{l}\text { Boeco-logical } \\
\text { group }\end{array}$} & $\begin{array}{l}\text { The species of meadow } \\
\text { grasses }\end{array}$ & Characteristics of cereals & $\begin{array}{l}\text { The average productive- } \\
\text { ness }( \pm \sigma), \mathrm{t} / \mathrm{ha}\end{array}$ \\
\hline \multirow{3}{*}{ Xero-mesoft } & Festuca ovina L. & grassroots slocombe & $6,90 \pm 0,7$ \\
\cline { 2 - 4 } & Dactilys glomerata L. & riding newlocale & $9,67 \pm 1,89$ \\
\hline \multirow{4}{*}{ Mesoft } & Agrostis gigantean Roth & napevi newlocale & $7,56 \pm 1,38$ \\
\cline { 2 - 4 } & Bromus inermis Leyss. & riding rhizomatous & $12,13 \pm 1,81$ \\
\cline { 2 - 4 } & Phleum pretense L & riding newlocale & $10,98 \pm 1,78$ \\
\cline { 2 - 4 } & Festuca pratensis Huds & napevi newlocale & $8,38 \pm 1,54$ \\
\cline { 2 - 4 } & Lolium perenne L & grassroots newlocale & $8,25 \pm 0,87$ \\
\cline { 2 - 4 } & Festuca rubra L. & $\begin{array}{l}\text { grassroots coronelismo- } \\
\text { newlinemode }\end{array}$ & $8,56 \pm 2,41$ \\
\hline \multirow{2}{*}{ Hygro-mesoft } & Alopecurus pratensis L. & $\begin{array}{l}\text { napevi } \\
\text { newlinemode }\end{array}$ & $10,59 \pm 2,36$ \\
\hline
\end{tabular}




\begin{tabular}{|l|l|l|l|}
\hline & Beckmannia eruciformis L. & horse, rhizomatous & $10,21 \pm 2,84$ \\
\cline { 2 - 4 } & Phalarodies arundinaceae L. & horse, rhizomatous & $12,90 \pm 1,52$ \\
\cline { 2 - 4 } & Festuca arundinaceae Shreb. & horse, rhizomatous & $9,34 \pm 1,11$ \\
\cline { 2 - 4 } & Poa palustris L. & horse, rhizomatous & $7,65 \pm 1,21$ \\
\hline
\end{tabular}

As shown by longitudinal studies, the least productive (6-8 t/ha) among the studied perennial grasses in drained peatlands in a single crop was sheep festuca ovina, agrostis gigantean roth and poa palustris. Average crop yields (8-10 t/ha) was in the lolium perenne, festuca pratensis, festuca rubra, festuca arundinaceae shreb and reed and dactilys glomerata. Consistently high performance (10-12 t/ha) reached beckmannia eruciformis, alopecurus pratensis and phleum pretense. So the average productivity of herbage phleum pretense, alopecurus pratensis and beckmannia eruciformis for the study years were above 10,0, and dactilys glomerata and the festuca arundinaceae shreb $-9,0 \mathrm{t} / \mathrm{ha}$. Phleum pretense and dactilys glomerata othy hedgehog in five 5-year cycles had yields in the range of 8,2-14,3 and 6,3-12,9 t/ha, respectively, and the alopecurus pratensis and beckmannia eruciformis ( 3 cycles for 5 years) $-7,0-14,1$ and 7,0-15,2 t/ha. The herbage of alopecurus pratensis for another $6-9$ years provided a yield of $9,4 \%$ and $11,5 \mathrm{t} / \mathrm{ha}$.

The highest yields were at the awnless bromus inermis leyss and phalarodies arundinaceae the average collection of dry substance ( 2 slopes) over 25 years of research amounted to more than 12,0 t/ha productivity phalarodies arundinaceae four 5-year cycle was: 1982-1986 - 13,2-14,2, 1987-1991 - 13,1$13,5,1996-2000-11,0-11,5$ and 2002-2006 - the 11,6-13,5 t/ha. Even at 6-9 years of use herbage reached $9,6-11,8$ t/ha. The productivity of awnless bromus inermis leyss 5 for a five-year rotation ranged from 9,1 to $14,8 \mathrm{t} / \mathrm{ha}$, providing on 5 -th year of use, 9,8-14,1, and 6 th $-10,0 \mathrm{t} / \mathrm{ha}$ of hay. Over the ten year period (19821991 g.g.) the yield of awnless bromus inermis leyss did not fall below the 13,0 t/ha regardless of the year of using grass.

In a parallel field experiments have been studied 8 traverses perennial meadow grasses under such options fertilizer: $\mathrm{P}_{60} \mathrm{~K}_{120}$ and $\mathrm{N}_{120} \mathrm{P}_{60} \mathrm{~K}_{120}$. In the experiments we used 2-hay mowing regime of the grass. Traverses part and the weight part of the components are given in table 2.

Studies have shown that the application of phosphorus-potash, and complete fertilizer perennial grass mix on reclaimed peat soils in an average 6-year cycle using grass provided the average yield of hay of more than $7 \mathrm{t} / \mathrm{ha}$, and in some cases, and more than $11 \mathrm{t} / \mathrm{ha}$ (table 2).

\section{Average long-term yield perennial meadow grasses depending on the fertilizer on drained peat} soils (2- slope using)

\begin{tabular}{|c|c|c|c|}
\hline № & Components in grass mix $(\mathrm{kg})$ & Fertilizer & $\begin{array}{l}\text { The yield-ness } \\
\text { of hay, } t / \text { ha }\end{array}$ \\
\hline \multirow{2}{*}{1} & \multirow{2}{*}{$\begin{array}{l}\text { Festuca pratensis (12), dactilys glomerata (12), phleum pretense } \\
\text { (7) }\end{array}$} & $\mathrm{P}_{60} \mathrm{~K}_{120}$ & 8,8 \\
\hline & & $\mathrm{N}_{120} \mathrm{P}_{60} \mathrm{~K}_{120}$ & 10,1 \\
\hline \multirow{2}{*}{2} & \multirow{2}{*}{$\begin{array}{l}\text { Festuca pratensis (12), dactilys glomerata (12), alopecurus } \\
\text { pratensis (7) }\end{array}$} & $\mathrm{P}_{60} \mathrm{~K}_{120}$ & 7,9 \\
\hline & & $\mathrm{N}_{120} \mathrm{P}_{60} \mathrm{~K}_{120}$ & 9,1 \\
\hline \multirow{2}{*}{3} & \multirow{2}{*}{$\begin{array}{l}\text { Festuca pratensis (12), dactilys glomerata (12), } \\
\text { agrostis gigantean roth ( } 7)\end{array}$} & $\mathrm{P}_{60} \mathrm{~K}_{120}$ & 7,0 \\
\hline & & $\mathrm{N}_{120} \mathrm{P}_{60} \mathrm{~K}_{120}$ & 9,9 \\
\hline \multirow{2}{*}{4} & \multirow{2}{*}{ Bromus inermis (12), festuca pratensis (12), phleum pretense (7) } & $\mathrm{P}_{60} \mathrm{~K}_{120}$ & 10,0 \\
\hline & & $\mathrm{N}_{120} \mathrm{P}_{60} \mathrm{~K}_{120}$ & 11,4 \\
\hline \multirow{2}{*}{5} & \multirow{2}{*}{ Bromus inermis (12), lolium perenne (12), phleum pretense (7) } & $\mathrm{P}_{60} \mathrm{~K}_{120}$ & 9,2 \\
\hline & & $\mathrm{N}_{120} \mathrm{P}_{60} \mathrm{~K}_{120}$ & 11,1 \\
\hline \multirow{2}{*}{6} & \multirow{2}{*}{ Bromus inermis (12), dactilys glomerata (12), phleum pretense (7) } & $\mathrm{P}_{60} \mathrm{~K}_{120}$ & 9,9 \\
\hline & & $\mathrm{N}_{120} \mathrm{P}_{60} \mathrm{~K}_{120}$ & 11,5 \\
\hline \multirow{2}{*}{7} & \multirow{2}{*}{$\begin{array}{l}\text { Festuca arundinaceae (12), alopecurus pratensis (7), agrostis } \\
\text { gigantean (6), phalarodies arundinaceae (6) }\end{array}$} & $\mathrm{P}_{60} \mathrm{~K}_{120}$ & 8,6 \\
\hline & & $\mathrm{N}_{120} \mathrm{P}_{60} \mathrm{~K}_{120}$ & 10,4 \\
\hline \multirow{2}{*}{8} & \multirow{2}{*}{$\begin{array}{l}\text { Bromus inermis (6), festuca pratensis (6), dactilys glomerata (6), } \\
\text { alopecurus pratensis }(5) \text {, } \\
\text { agrostis gigantean (4), phleum pretense (4) }\end{array}$} & $\mathrm{P}_{60} \mathrm{~K}_{120}$ & 9,5 \\
\hline & & $\mathrm{N}_{120} \mathrm{P}_{60} \mathrm{~K}_{120}$ & 11,4 \\
\hline & \multirow{2}{*}{ The average for the fertilizer variants: } & $\mathrm{P}_{60} \mathrm{~K}_{120}$ & 8,9 \\
\hline & & $\mathrm{N}_{120} \mathrm{P}_{60} \mathrm{~K}_{120}$ & 10,6 \\
\hline
\end{tabular}


Studies have shown that the most productive on drained peat soils proved to be grass mix involving awnless bromus inermis, phleum pretense, dactilys glomerata and festuca pratensis. So, when you make a complete fertilizer in normal $\mathrm{N}_{120} \mathrm{P}_{60} \mathrm{~K}_{120}$ the yield of hay grass mix created on the basis of these types of made 11,4-11,5 t/ha. it Should be noted that in grass mix, where instead of awnless bromus inermis was included in a different form, experienced a decline in their yields, especially with the aging of grass. This is because maximum performance bromus inermis provides starting from 3-4 years of use. Therefore, it should be included in grass mix that long-term use.

Thus, the conducted research give grounds to recommend on drained peat soils to grow grass mix of phleum pretense, festuca pratensis and dactilys glomerata, bromus inermis, which upon application of a full fertilizer in a normal $\mathrm{N}_{120} \mathrm{P}_{60} \mathrm{~K}_{120}$ (average 6 years) provides the 11,4-11,5 t/ha of hay.

Average yield increase grass mix from the use of complete mineral fertilizers, compared to bezitten, was $1,7 \mathrm{t} / \mathrm{ha}$ or $19 \%$. This confirms the feasibility of nitrogen fertilizer on peat soils on herbage long-term use, especially beginning in the third year.

In the field experiment, which was conducted in 2008-2010, five species of perennial grasses and 4 grass mixtures were studied at their different ratios, with the participation of the bean component - the lotus corniculatus, lotus uliginosus. Yields of perennial grasses and their grass mixtures are shown in table 3 .

\section{The yield of hay of perennial grasses, depending on the modes of fertilizer and mowing on drained peat soils Sarny experimental station (average over 2008-2010, t/ha)}

\begin{tabular}{|c|c|c|c|c|c|c|c|c|}
\hline \multirow[b]{2}{*}{$\begin{array}{c}\text { Species of perennial grasses and } \\
\text { their mixtures }\end{array}$} & \multicolumn{3}{|c|}{ Dose use } & \multicolumn{3}{|c|}{ Triune use } & \multirow[b]{2}{*}{ 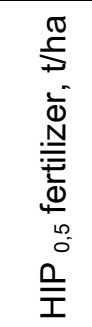 } & \multirow[b]{2}{*}{ 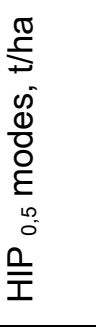 } \\
\hline & 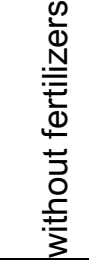 & 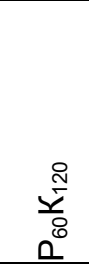 & 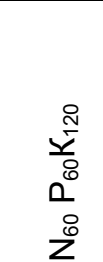 & 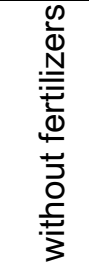 & 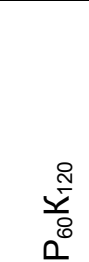 & $\begin{array}{l}\frac{2}{2} \\
\frac{1}{8} \\
0 \\
0 \\
z\end{array}$ & & \\
\hline Bromus inermis & 2,85 & 8,04 & 9,74 & 2,46 & 7,30 & 8,78 & 0,35 & 0,17 \\
\hline Phleum pretense & 2,64 & 7,43 & 8,99 & 2,28 & 6,76 & 7,62 & 0,29 & 0,15 \\
\hline Lolium perenne & 2,02 & 5,05 & 5,62 & 2,07 & 5,20 & 6,19 & 0,27 & 0,13 \\
\hline Beckmannia eruciformis & 2,64 & 6,82 & 8,46 & 2,25 & 6,35 & 7,61 & 0,22 & 0,11 \\
\hline Festuca ovina & 2,52 & 5,49 & 6,47 & 2,22 & 5,46 & 6,27 & 0,32 & 0,16 \\
\hline Lotus corniculatus & 3,04 & 5,28 & 5,68 & 2,43 & 4,85 & 5,03 & 0,28 & 0,14 \\
\hline Lotus uliginosus & 2,56 & 4,66 & 5,36 & 1,74 & 4,25 & 4,63 & 0,29 & 0,14 \\
\hline Grass mix 1 & 2,88 & 8,15 & 9,41 & 2,81 & 7,77 & 9,25 & 0,39 & 0,19 \\
\hline Grass mix 2 & 3,03 & 8,59 & 9,98 & 3,00 & 8,30 & 9,79 & 0,28 & 0,14 \\
\hline Grass mix 3 & 3,13 & 8,75 & 10,45 & 3,05 & 8,46 & 9,98 & 0,30 & 0,15 \\
\hline Grass mix 4 & 3,09 & 8,73 & 10,27 & 3,01 & 8,44 & 9,90 & 0,36 & 0,18 \\
\hline
\end{tabular}

Studies have shown that stereomic, well-decomposed peat of the simple three or four component grass mix from awnless bromus inermis, phleum pretense, lolium perenne, lotus corniculatus, lotus uliginosus average in 2008-2010 when making a complete fertilizer in normal $\mathrm{N}_{60} \mathrm{P}_{60} \mathrm{~K}_{120}$ provided $10,4-11,7 \mathrm{t} /$ ha of dry mass, while the monospecific plantings of these grasses - 5,92-10,9 $\mathrm{t} / \mathrm{ha}$. Application of phosphorus-potash fertilizer at norm $\mathrm{P}_{60} \mathrm{~K}_{120}$ provided the increase in yield of perennial grasses compared to not fertilized plots 1,7-3,0 times and 1,9-3,6 times for making $\mathrm{N}_{60} \mathrm{P}_{60} \mathrm{~K}_{120}$. The application of a full fertilizer in a normal $\mathrm{N}_{60} \mathrm{P}_{60} \mathrm{~K}_{120}$ provided increase in yield of perennial grasses compared to application of phosphorus-potash fertilizer at norm $\mathrm{P}_{60} \mathrm{~K}_{120}$ in $4-28 \%$. With the aging of the mixtures effectiveness of mineral fertilizers increased.

The obtained results give grounds to recommend for implementation in the production of this still rare species of herbs like beckmannia eruciformis, particularly in wet soil, while introducing a complete mineral fertilizer provided a yield of the dry mass of 8,55-of 9,55 t/ha, while the traditional drained peatlands grass - phleum pretense - of 8,56-10,1 t/ha, besides the latter is more demanding on water and nutrient regime of the soil.

The sheep festuca ovina, and lotus corniculatus in making complete fertilizer in normal $\mathrm{N}_{60} \mathrm{P}_{60} \mathrm{~K}_{120}$ provided stable during the three years, yield $-7,15-7,24$ and 5,67-of 6,24 t/ha dry weight, which shows the possibility of growing these species in terms stroomi drained peatlands. 
It is known that peat soil is sufficiently provided with nitrogen, in spite of this for growing most agricultural crops, it is recommended to only make phosphorus-potassium fertilizer. However, perennial grasses with the ageing of the herbage form a durable turf that slows the mineralization of organic matter of peat and as a result of the release of nutrients (including nitrogen) is also reduced. Therefore, nitrogen fertilizers for perennial grasses on peat soils it is recommended to apply from the 3rd year of use. In the literature there are different views on the value of the norm of nitrogen fertilizer when growing on drained peatlands. So the study travassac that have been performed in 1982-2007 years (second experience), the norm of nitrogen fertilizers amounted to $\mathrm{N}_{120}$, while in the experiment carried out in 2008-2010 (the third experiment) - $\mathrm{N}_{60}$, i.e. less than half. Analysis of yield grass mix № 5 ( 2 experience) and grass mix 2 ( 3 experience), which consisted of awnless brome, Timothy meadow and perennial ryegrass showed how full of mineral fertilizers in norm $\mathrm{N}_{60} \mathrm{P}_{60} \mathrm{~K}_{120}$ and for making $\mathrm{N}_{120} \mathrm{P}_{60} \mathrm{~K}_{120}$ she was close in magnitude. This gives grounds to assert that the economically optimum application rate of nitrogen for perennial grasses on drained peat soils in snakea use is $\mathrm{N}_{60}$, starting from the third year of use the herbage.

\section{Conclusions.}

It is established that the most productive species of perennial grasses on drained peat soils is a common phalarodies arundinaceae, bromus inermis, phleum pretense, alopecurus pratensis, beckmannia eruciformis which in single-species grass mix for prolonged use provides the average yield of hay 10-12 $t$ /ha or more. Among grass mix snakea long-term use of the most productive is a mix of phleum pretense, festuca pratensis and dactilys glomerata of awnless brome. Also promising is travasso from awnless bromus inermis.

Also promising is the grass mix from the stoic of the seamless, the bromus inermis, phleum pretense, lolium perenne of the ray, the long-lasting pineapple which includes lotus uliginosus.

Optimal for their cultivation on drained organic soils is 2 hay mode of using grass with an annual application of mineral fertilizers in norm $\mathrm{P}_{60} \mathrm{~K}_{120}$ plus $\mathrm{N}_{60}$ starting from the third year of use.

\section{Bibliography}

1. Bogovin A.V., Slyusar I.T., Tsarenko M.K. (2005). Herbal biogeocoenoses, their improvement and rational use. Kyiv: Agrarian Science. $360 \mathrm{p}$.

2. Kurgach V.G. (2010). Onion agrophytocenoses. Kyiv: Dia. 370 p.

3. Meerovsky A.S., Brel S.N. (2010). The cultivation of long-term meadow grasslands - a way of preserving peat soils. Soil fertility - the basis of sustainable development of agriculture: materials International. scientific practice. conf. and IV Congress of Soil Scientists, Minsk, July 26-30, 2010 y: 2 hours / rareology.: V.V. Lapa [and others]; Institute of Soil Science and Agrochemistry. Minsk. Ch.1. P. 123-125.

4. Ryzhuk S.M., Slysiar I.T., Vergunov V.A. (2002). Agro-ecological features of highly effective use of drained peat soils of Polissya and Forest-steppe: textbook. Kyiv: Agrarian Science. 402 p.

5. Slyusar I.T., Zosimchyk M.D. (2010). Productivity of perennial grasses on radioactive contaminated peat soils of Western Polissya. Collection of scientific works of the National Academy of Sciences of Ukraine Institute of Agriculture of UAAS, issue. 1-2. P. 31-39.

6. Vlokh V.G. Kirichenko N.Y., Cogut P.M. (2003). Lukovestvo. Kyiv: Harvest. 385 p.

7. Pikun P.T. (2010). Productivity of perennial grasses in peat-swamp soils. Our agriculture. №. 11. P. 78-81.

8. Stetsiuk M.G. (2008). Forage and seed yield of cereals on reclaimed organogenic soils of Western Polissya. Feed and Forage Production. Vinnytsya. P. 89-102.

9. Truskavetski R.S. (2010). Peat soils and peatlands of Ukraine. Kharkiv: Miskdruk. 278 p.

10. linicki P. (2002). Torfowiska i torf. Poznan, Poland. 606 p.

11. Biodiversity and Animal Feed Future Challenges for Grassland Production Proceeding of the 22 th General Meeting of the European Grassland Federation Uppsala, Sweden 9-12 June, 2008. V. 13. 1035 p.

12. Andrienko T.L. (1999). Florist and coenotic diversity of peat-ecosystems and their perspectives in Ukraine. Ways to improve the conservation of peat and other types of marshes in Ukraine. Kyiv: The Darwinian Initiative Program. P. 16-19. 